RASĀYAN J. Chem.

Vol. 14 | No. 3 |1635-1642| July - September | 2021

ISSN: 0974-1496 | e-ISSN: 0976-0083 | CODEN: RJCABP http://www.rasayanjournal.com

\title{
SYNTHESIS AND STUDIES ON NOVEL TOLUIC ACID-BASED AZO DYES
}

\author{
A.G. Prashantha ${ }^{1}$, J. Keshavayya ${ }^{1 凶}$ and R. A. Shoukat Ali ${ }^{2}$ \\ ${ }^{1}$ Department of PG Studies and Research in Chemistry, Kuvempu University, \\ Shankaraghatta -577 451, Shimoga, Karnataka, India \\ ${ }^{2}$ Department of Studies and Research in Chemistry, Davangere University \\ Davangere-577 007, Davangere, Karnataka, India \\ ${ }^{\circledR}$ Corresponding Author: jathikeshavayya1959@gmail.com
}

\begin{abstract}
In the present research paper, we have reported a series of new azo acidic dyes, which are synthesized by diazo coupling of 3-amino-4-methyl-benzoic acid with cresol and different substituted naphthols. The synthesized dyes are characterized by various techniques like UV-Vis absorption spectral, IR spectral, ${ }^{1} \mathrm{H}$ NMR spectral, and Mass spectrometric methods. The electrochemical behavior of different azo dyes was studied in the sulphuric acid medium using cyclic voltammetry. Finally, the synthesized azo dyes are subjected to primary investigation of antimicrobial activity against a common fungus Fusareumoxysporum and bacteria P-aureus and S.-aureus.
\end{abstract}

Keywords: Azo Dyes, Synthesis and Characterization, Application Studies

RASĀYAN J. Chem., Vol. 14, No.3, 2021

\section{INTRODUCTION}

Azo compounds are an important class of organic colorants and consist of at least a conjugated chromophore azo $(-\mathrm{N}=\mathrm{N}-)$ group and two or more aromatic rings. The coloring properties of organic dyes depend on both the presence of the chromophore groups and the crystallographic arrangement of molecules in the solid state. ${ }^{1}$ It has been known for many years that azo compounds are the most widely used class of dyes due to their versatile application in various fields such as the dyeing of textiles and polymers. ${ }^{2-3}$ Apart from these, non-toxic colorants are used in dyeing foodstuffs, pharmaceuticals, and cosmetics, high technology fields such as electronic storage devices ${ }^{4}$, linear and non-linear optics ${ }^{5}$, reprography, sensors ${ }^{6}$ and biomedical uses. Azo dyes have also been used as catalysts, semiconductors, photoconductors, photosensitizers, corrosion inhibitors, solar cell functioning materials, gas sensors, nonlinear optical limiting devices. ${ }^{7-10}$ Recently synthesis and antimicrobial evaluation of some novel 4hydroxy coumarin derivatives bearing azo moiety was reported ${ }^{11}$ and the effect of metal ions as dyesensitized solar cells was also reported. ${ }^{12}$ For two and half decades in our research laboratory, different derivatives of azo dyes were synthesized, characterized and explored their applications in various fields and reported in reputed journals. ${ }^{13-18}$ The present study investigates different approaches for the synthesis of some novel alkali clearable azo dyes derived from reacting 3-amino-4-methyl benzoic acid with resorcinol and different naphthols as coupling components. The reason for selecting 3-amino-4-methyl benzoic acid is that, due to the presence of the carboxylic acid group, it becomes alkali-soluble.

\section{Material and Methods}

\section{EXPERIMENTAL}

3-amino-4-methyl-benzoic acid was purchased from Sigma Aldrich. It is directly used as such for diazotization reaction. The commercial-grade coupling components were purified by recrystallization from Ethanol and used for the coupling. Infrared spectra of synthesized azo dyes were recorded in the region of $400 \mathrm{~cm}^{-1}$ to $4000 \mathrm{~cm}^{-1}$ on an FT-IR-460 Spectrometer in $\mathrm{KBr}$ pellets. The mass spectra were recorded with an LC-MS-trap-XCTplus mass spectrometer. The ${ }^{1} \mathrm{H}$ NMR spectra were recorded in DMSO- $_{6}$ at $400 \mathrm{MHz}$ using AMX-400 FT-NMR spectrophotometer using TMS as internal standard. The UV-Visible absorption spectra were recorded in, DMSO solvent with a SHIMADZU UV-Visible 1650 
RASĀYAN J. Chem.

Vol. 14 | No. 3 |1635-1642 | July - September | 2021

spectrometer in the wavelength range of $200-800 \mathrm{~nm}$. The melting point was recorded using the electrical instrument.

\section{General Procedure for the Synthesis of the Azo Dyes Diazotization and Coupling}

The $0.5 \mathrm{~g}(0.003 \mathrm{~m}) 3$-amino-4-methyl benzoic acid was dissolved in $6 \mathrm{ml}$ of acetic acid than $2 \mathrm{ml}$ of conc. sulphuric acid was added to it. An equimolar (1:1) mixture of $\mathrm{NaNO}_{2}, 0.45 \mathrm{~g}(0.003 \mathrm{~m})$ was slowly added with stirring. The reaction mixture was stirred for $2 \mathrm{hrs}$ maintaining the temperature of $0-5^{\circ} \mathrm{C}$. The excess $\mathrm{NaNO}_{2}$ was destroyed by adding the required quantity of urea. The $\mathrm{pH}$ of the reaction mixture was maintained at 6 by adding a chilled aqueous solution of sodium carbonate. A solution containing an equimolar mixture of coupling components taken in DMF $(20 \mathrm{~mL})$ was added to the reaction mixture and stirred for $4 \mathrm{hrs}$. The dye obtained was filtered, washed with hot water, dried, and recrystallized from ethanol. The purity of the compound was checked by thin-layer chromatography. The general reaction path was shown in Scheme-1 and the structures of different coupling components and the corresponding dyes obtained were also displayed.

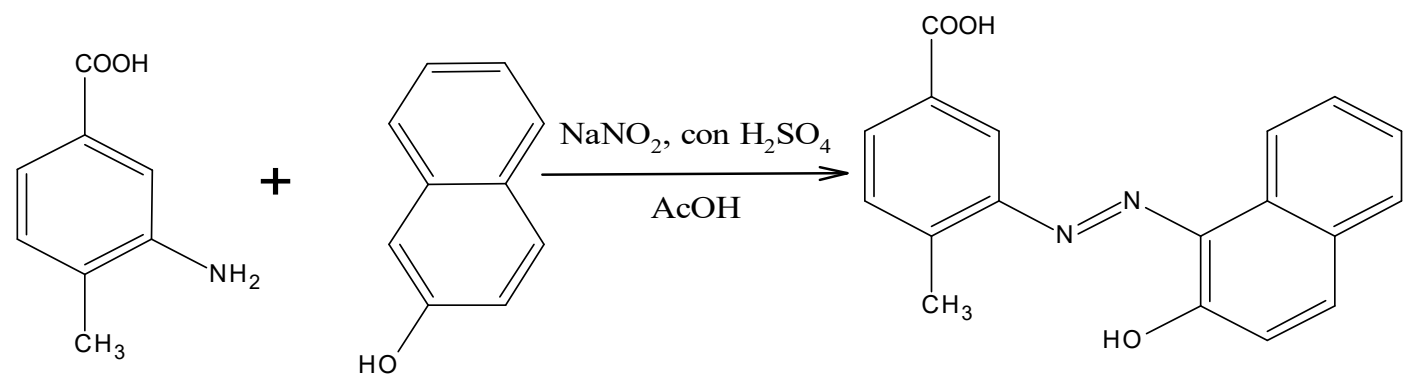

3-amino-4-methylbenzoic acid

Scheme-1: General Synthetic Route of Azo Dyes

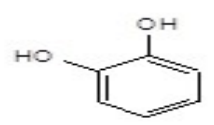

Coupling Component [CC]-1

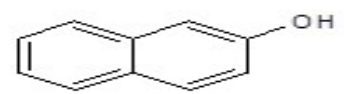

Coupling Component [CC]-2
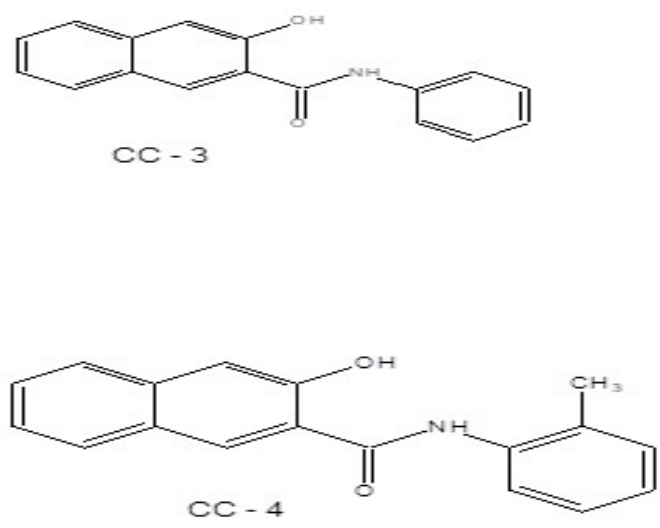<smiles>Cc1ccc(CCNCc2cccc(Cl)c2Cl)c(O)c1</smiles><smiles>Cc1ccc(C(=O)O)cc1N=Cc1cccc2ccccc12</smiles><smiles>Cc1ccc(O)cc1C=NC1=CC2CC=CCC2C=C1C(=O)Nc1ccccc1</smiles><smiles>Cc1ccc(C(=O)O)cc1N=Nc1c(O)c(C(=O)Nc2ccccc2C)cc2ccccc12</smiles> 
RASĀYAN J. Chem.

Vol. 14 | No. 3 |1635-1642| July - September | 2021<smiles>COc1ccccc1NC(=O)c1cc2ccccc2cc1O</smiles>

$\mathrm{CC}-5$<smiles>O=C(Nc1cccc([N+](=O)[O-])c1)c1cc2ccccc2cc1O</smiles>

CC -6<smiles>O=C(Nc1cccc2ccccc12)c1cc2ccccc2cc1O</smiles>

$\mathrm{CC}-7$<smiles>COc1ccccc1NC(=O)c1cc2ccccc2c(/N=N/c2cc(C(=O)O)ccc2C)c1O</smiles><smiles>Cc1ccc(C(=O)O)cc1/N=N/c1c(O)c(C(=O)Nc2cccc([N+](=O)[O-])c2)cc2ccccc12</smiles><smiles>Cc1ccc(C(=O)O)cc1/N=N/c1c(O)c(C(=O)Nc2cccc3ccccc23)cc2ccccc12</smiles><smiles>CC(=O)CC(=O)Nc1ccc(-c2ccc(NC(=O)CC(C)=O)c(NC(=O)CC(=O)Nc3ccc(-c4ccc(NC(=O)C(N=Nc5cc(C(=O)O)ccc5C)C(C)=O)c(C)c4)cc3C)c2)cc1C</smiles>

CC -8

Fig.-1: Structures of Various Coupling Components (CC:1-8) and Azo Dyes(1-8)

\section{Electronic Spectral Studies}

\section{RESULTS AND DISCUSSION}

The electronic spectra were recorded in the range 200-800 $\mathrm{nm}$ taking DMSO as solvent at the concentration of $5 \times 10^{-5} \mathrm{M}$. Due to the electronic transition of $\pi \rightarrow \pi^{*}$ in the azo group, the absorption maxima of the compounds (dyes 1-7) lies in the range of 485 to $528 \mathrm{~nm}$ with the marginal variation. The dyes 4,5,6,7 show two absorption bands. The values are as shown in the table. The first band corresponds 
to the azo group and the other to the hydrazone configuration. The dye 8 underwent hypochromic shift compared to other dyes due to the coupling to the active methylene group present in the coupling component 8 . The $\log \epsilon$ values are given in Table-2.

Table-2: Spectral Data of Compounds

\begin{tabular}{c|c|c}
\hline Name ofCompound & $\begin{array}{c}\lambda_{\max } \\
\text { in } \mathrm{nm}\end{array}$ & $\log \epsilon$ \\
\hline Dye-1 & 490 & 3.2 \\
\hline Dye-2 & 485 & 3.51 \\
\hline Dye-3 & 512 & 3.02 \\
\hline \multirow{2}{*}{ Dye-4 } & 529 & 3.58 \\
\cline { 2 - 3 } & 511 & 3.58 \\
\hline \multirow{2}{*}{ Dye-5 } & 527 & 3.47 \\
\hline \multirow{2}{*}{ Dye-6 } & 505 & 3.47 \\
\hline \multirow{2}{*}{ Dye-7 } & 503 & 2.92 \\
\hline Dye-8 & 528 & 3.29 \\
\cline { 2 - 3 } & 504 & 3.29 \\
\hline & 385 & 3.87 \\
\hline
\end{tabular}

The IR spectrum of the compound showed a prominent absorption band at the stretching frequency at $3639 \mathrm{~cm}^{-1}$, for $-\mathrm{OH}$ starching frequency at $3470 \mathrm{~cm}^{-1}$, for $-\mathrm{NH}$ stretching $1554 \mathrm{~cm}^{-1}$ for $-\mathrm{C}=\mathrm{O} 1509 \mathrm{~cm}^{-1}$ for $-\mathrm{N}=\mathrm{N}-$ and $3034 \mathrm{~cm}^{-1}$ for (-CO-NH-) stretching.

The1H NMR spectrum of the dye-2 was recorded in Dmso-d6. The Assignments are based on an earlier report. The ${ }^{1}$ H-NMR spectrum of the dye-2 showed a sharp singlet for the methyl group at $\delta$ value $3.32 \mathrm{ppm}$. For the 9-Aromatic protons signals found in the range 6.92-8.5 ppm. A broad peak corresponding to $-\mathrm{COOH}$ proton was observed at $\delta$ value $13.19 \mathrm{ppm}$.

The mass spectrum of the dye-2 shows a molecular ion peak of $(\mathrm{m} / \mathrm{z})$ at 306 agrees with the molecular mass of the compound. In a similar way all the synthesized dyes were characterized, and the data is given below.

Spectral Data of 2-[(E)-(2,3-dihydroxyphenyl)diazenyl]-4-methylbenzoic acid, (Dye-1)

Yield: $82 \%$; M.W: 272.0 M.F: $\mathrm{C}_{14} \mathrm{H}_{12} \mathrm{~N}_{2} \mathrm{O}_{4}$; M p:262-264 ${ }^{\circ} \mathrm{C}$; IR (KBr): $\bar{\nu}=3639 \mathrm{~cm}^{-1}(\mathrm{OH}), 3470 \mathrm{~cm}^{-1}$ $(\mathrm{NH}), \quad 1684.52 \mathrm{~cm}^{-1}(\mathrm{C}=\mathrm{O}), 1593 \mathrm{~cm}^{-1}(\mathrm{~N}=\mathrm{N})$, LC-MS $\left(\mathrm{M}^{+1}\right) \mathrm{m} / \mathrm{z}=272.2$, NMR $\left(\mathrm{DMSO}^{6}\right.$, ppm), 12.90(br, 1H, COOH), 13.11(br, 1H, OH), 10.68(br, 1H, OH), 6.37-8.4(6H, Ar-H) 3.32(s, $\left.\mathrm{CH}_{3}\right)$.

Spectral Data of, 3-[(E)-(2-hydroxynaphthalen-1-yl)diazenyl]-4-methylbenzoic acid, (Dye-2)

Yield: 85\%; M.W: 306.00; M.F: $\mathrm{C}_{18} \mathrm{H}_{14} \mathrm{~N}_{2} \mathrm{O}_{3}$; mp:-296-293 ${ }^{\circ} \mathrm{C}$; IR (KBr): $\bar{\nu}=3639 \mathrm{~cm}^{-1}(\mathrm{OH}), 3470 \mathrm{~cm}^{-1}$ $(\mathrm{NH}), 1617 \mathrm{~cm}^{-1}(\mathrm{C}=\mathrm{O}), 1554 \mathrm{~cm}^{-1}(\mathrm{~N}=\mathrm{N}), 1509 \mathrm{~cm}^{-1}(\mathrm{CONH}) 3034.44 \mathrm{~cm}^{-1}(\mathrm{Ar}-\mathrm{CH}) \mathrm{LCMS}\left(\mathrm{M}^{+1}\right) \mathrm{m} / \mathrm{z}=$ 307.20 NMR (DMSO-d ${ }^{6}$, ppm), 3.32(s, $\left.\mathrm{CH}_{3}\right), 6.90-8.50(9 \mathrm{H}, \mathrm{Ar}-\mathrm{H}) .13 .19(\mathrm{br}, 1 \mathrm{H}, \mathrm{COOH})$.

Spectral Data of, 3-[(E)- (3-hydroxy-N-phenylnaphthalene-2-carboxamide) diazenyl $] \quad$-4methylbenzoic acid,(Dye-3)

Yield: 72\%; M.W: 425.0; M.F: $\mathrm{C}_{25} \mathrm{H}_{18} \mathrm{~N}_{4} \mathrm{O}_{6} ; \mathrm{mp}: 250-253^{\circ} \mathrm{C}$; IR (KBr): $\bar{\nu}=3639 \mathrm{~cm}^{-1}(\mathrm{OH}), 3470 \mathrm{~cm}^{-1}$ $(\mathrm{NH}), 1621 \mathrm{~cm}^{-1}(\mathrm{C}=\mathrm{O}), 1558.2 \mathrm{~cm}^{-1}(\mathrm{~N}=\mathrm{N}), 1490.7 \mathrm{~cm}^{-1}(-\mathrm{CONH}), 3050.8 \mathrm{~cm}^{-1}(\mathrm{Ar}-\mathrm{CH})$, LC-MS $\left(\mathrm{M}^{+1}\right)$ $\mathrm{m} / \mathrm{z}=426.2 \quad \mathrm{NMR}\left(\mathrm{DMSO}-\mathrm{d}^{6}, \quad \mathrm{ppm}\right) \quad 3.33\left(\mathrm{~s}, \mathrm{CH}_{3}\right), \quad 7.13-8.74(13 \mathrm{H}, \mathrm{Ar}-\mathrm{H}) \quad, 10.59(\mathrm{br}, 1 \mathrm{H}, \mathrm{OH})$, $11.32(\mathrm{br}, 1 \mathrm{H}, \mathrm{COOH})$.

Spectral Data of, 3-[(E)-(3-hydroxy-N-(2-methylphenyl)naphthalene-2-carbox mide) diazenyl]-4methylbenzoic acid, (Dye-4): Yield: 81\%; M.W: 425.0; M.F: $\mathrm{C}_{26} \mathrm{H}_{21} \mathrm{~N}_{3} \mathrm{O}_{4}$; mp: $>286-288^{\circ} \mathrm{C}$; IR (KBr): $\bar{\nu}=3639 \mathrm{~cm}^{-1}(\mathrm{OH}), 3470 \mathrm{~cm}^{-1}(\mathrm{NH}), 1694.16 \mathrm{~cm}^{-1}(\mathrm{C}=\mathrm{O}), 1604.56 \mathrm{~cm}^{-1}(\mathrm{~N}=\mathrm{N}), 1549.52 \mathrm{~cm}^{-1}(-\mathrm{CONH})$, $3066.23 \mathrm{~cm}^{-1}(\mathrm{Ar}-\mathrm{CH}) \mathrm{LC}-\mathrm{MS}\left(\mathrm{M}^{+1}\right) \mathrm{m} / \mathrm{z}=426.1$, NMR(DMSO-d $\left.{ }^{6}, \mathrm{ppm}\right)$ 2.49-2.60(t, $\left.\mathrm{CH}_{3}\right), 3.88\left(\mathrm{~s}, \mathrm{CH}_{3}\right)$, 6.98-8.93(12H,Ar-H), 13.20-11.90 (br, 1H,OH), (br,1H,COOH). 
RASĀYAN J. Chem.

Vol. 14 | No. 3 |1635-1642| July - September | 2021

Spectral Data of, 3-[(E)-(3-hydroxy-N-(2-methoxyphenyl)naphthalene-2-carboxamide)diaze nyl] -4methylbenzoic acid, (Dye-5)

Yield: 78\%; M.W: 456.0; M.F: $\mathrm{C}_{26} \mathrm{H}_{21} \mathrm{~N}_{3} \mathrm{O}_{5} ; \mathrm{mp}:>300{ }^{\circ} \mathrm{C}$; IR $(\mathrm{KBr}): \bar{\nu}=3639 \mathrm{~cm}^{-1}(\mathrm{OH}), 3470 \mathrm{~cm}^{-1}$ $(\mathrm{NH}), 1695.3 \mathrm{~cm}^{-1}(\mathrm{C}=\mathrm{O}), 1602.56 \mathrm{~cm}^{-1}(\mathrm{~N}=\mathrm{N}), 1546.63 \mathrm{~cm}^{-1}(-\mathrm{CONH}), 3067.23 \mathrm{~cm}^{-1}(\mathrm{Ar}-\mathrm{CH})$, LC-MS $\left(\mathrm{M}^{+1}\right) \mathrm{m} / \mathrm{z}=456.2$, NMR (DMSO-d $\left.{ }^{6}, \mathrm{ppm}\right) \quad$ 2.5-2.62 $\left(\mathrm{d}, \mathrm{CH}_{3}\right), 3.94\left(\mathrm{~s}, \mathrm{OCH}_{3}\right), 6.98-8.93(12 \mathrm{H}, \mathrm{Ar}-\mathrm{H})$, 12.04(br,1H,COOH), 13.29(br,s,OH).

Spectral Data of, 3-[(E)- (3-hydroxy-N-(3-nitrophenyl)naphthalene-2-carbox amide) diazenyl]-4methylbenzoic acid, (Dye-6)

Yield: 79\%; M.W: 461.0; M.F: $\mathrm{C}_{25} \mathrm{H}_{18} \mathrm{~N}_{4} \mathrm{O}_{6}$; mp: $270-274^{\circ} \mathrm{C}$; IR (KBr) : $\bar{\nu}=3639 \mathrm{~cm}^{-1}(\mathrm{OH}), 3470 \mathrm{~cm}^{-1}$ $(\mathrm{NH}), 1681.6 \mathrm{~cm}^{-1}(\mathrm{C}=\mathrm{O}), 1601.59 \mathrm{~cm}^{-1}(\mathrm{~N}=\mathrm{N}), 1531.63 \mathrm{~cm}^{-1}(-\mathrm{CONH}), 3118.33 \mathrm{~cm}^{-1}(\mathrm{Ar}-\mathrm{CH})$ LC-MS $\left(\mathrm{M}^{+1}\right) \mathrm{m} / \mathrm{z}=462.1, \mathrm{NMR}\left(\mathrm{DMSO}-\mathrm{d}^{6}, \mathrm{ppm}\right) 3.31\left(\mathrm{~s}, \mathrm{CH}_{3}\right), 6.91-8.34(11 \mathrm{H}, \mathrm{Ar}-\mathrm{H}), 11.9(\mathrm{br}, 1 \mathrm{H}, \mathrm{OH})$.

Spectral Data of ,3-[(E)- (3-hydroxy-N-(naphthalen-1-yl)naphthalene-2-carbox amide) diazenyl]-4methylbenzoic acid, (Dye-7)

Yield: 86\%; M.W: 474.0; M.F: $\mathrm{C}_{29} \mathrm{H}_{21} \mathrm{~N}_{3} \mathrm{O}_{4}$; mp: $>300{ }^{\circ} \mathrm{C}$; IR $(\mathrm{KBr}): \bar{\nu}=3639 \mathrm{~cm}^{-1}(\mathrm{OH}), 3470 \mathrm{~cm}^{-1}$ $(\mathrm{NH}), 1651.3 \mathrm{~cm}^{-1}(\mathrm{C}=\mathrm{O}), 1602.56 \mathrm{~cm}^{-1}(\mathrm{~N}=\mathrm{N}), 1548.56 \mathrm{~cm}^{-1}(-\mathrm{CONH}), 3059.51 \mathrm{~cm}^{-1}$ (Ar-CH) LC-MS $\left(\mathrm{M}^{+1}\right) \mathrm{m} / \mathrm{z}=476.0$ NMR(DMSO-d $\left.{ }^{6}, \mathrm{ppm}\right), 3.87\left(\mathrm{~s}_{1} \mathrm{CH}_{3}\right), \quad 6.92-8.84(15 \mathrm{H}, \mathrm{Ar}-\mathrm{H}), 13.3$ (br,1H,OH), 11.9(br,1H,COOH).

Spectral Data of 3-[(E)- N-[2-methyl-4-[3-methyl-4-(3-oxobutanoylamino) phenyl] phenyl]-3-oxobutanamide) dizenyl ]-4-methylbenzoic acid, (Dye-8)

Yield: 80\%; M.W:542 ; M.F: $\mathrm{C}_{30} \mathrm{H}_{18} \mathrm{~N}_{4} \mathrm{O}_{6}$; mp: $>300{ }^{\circ} \mathrm{C}$; IR $(\mathrm{KBr}): \bar{\nu}=3639 \mathrm{~cm}^{-1}(\mathrm{OH}), 3470 \mathrm{~cm}^{-1}$ $(\mathrm{NH}), 1623.23 \mathrm{~cm}^{-1}(\mathrm{C}=\mathrm{O}), 1515.78 \mathrm{~cm}^{-1}(\mathrm{~N}=\mathrm{N}), 1455.99 \mathrm{~cm}^{-1}(-\mathrm{CONH}), 3239.82 \mathrm{~cm}^{-1}$ (Ar-CH) LC-MS $\left(\mathrm{M}^{+1}\right) \mathrm{m} / \mathrm{z}=541.2 \quad \mathrm{NMR}$, (DMSO-d $\left.{ }^{6}, \mathrm{ppm}\right), 2.20-2.50\left(2 \mathrm{~d}\left(2.39-2.40,2 \mathrm{CH}_{3}\right) \mathrm{s}\left(2.22-2.27 \mathrm{CH}_{3}\right) \mathrm{d}(2.49-\right.$ 2.56, $\left.\mathrm{CH}_{3}\right), 3.60\left(\mathrm{~s}, \mathrm{CH}_{2}\right), 7.40-8.20(15 \mathrm{H}, \mathrm{Ar}-\mathrm{H}), 9.50(\mathrm{~s}, \mathrm{NH}), 11.4(\mathrm{~s}, 1 \mathrm{H}, \mathrm{NH}), 13.3(\mathrm{br}, 1 \mathrm{H}, \mathrm{COOH})$.

\section{Electrochemical Behavior}

A few pieces of literature are available based on the voltammetric study of azo dyes These contain $\mathrm{N}=\mathrm{N}$ group which is easily reducible. The Oxidation-reduction behavior of these compounds plays an important role in their biological activity. In this present work, the electrochemical behavior of different dyes prepared was studied in the sulphuric acid medium, which is a supporting electrolyte on the glassy carbon electrode. The dyes (1-8) were dissolved in Dimethyl sulphoxide to prepare $1 \mathrm{X}^{-3} 0^{-3} \mathrm{M}$. solution, sulphuric acid concentration was maintained at $1 \times 10^{-2} \mathrm{M}$.

\section{The Irreversible Electrochemical Character of Azo Dyes (1-8)}

All the dyes contain electroactive species with an azo group $(-\mathrm{N}=\mathrm{N}-)$. The azo group is easily reduced on Glassy carbon electrodes. The cyclic voltammogram of 1X10-3 M concentrated dyes (1-8), recorded in $1 \mathrm{X} 10-2 \mathrm{M}$ conc. sulphuric acid was as shown in the voltammogram (1-8). The reduction peak is assigned to an azo group in the range -350 to- $650 \mathrm{mV}$. The irreversibility was confirmed by the absence of an anodic peak in voltammograms between the potential of $+350 \mathrm{mV}$ to $+650 \mathrm{mV}$. The different dye shows reductive peak $(\mathrm{EPc} 1)$ and $(\mathrm{EPc} 2) \mathrm{mV} / \mathrm{s}$ potentials. The values are given in Table-3. The general mechanism of reduction is a two-step one electron change of the azo group, which is similar to the literature, reduction of Erichrome black - T. The reduction process is as shown below (4.3). The multiple cycles were applied, which results in a great decrease in the reductive peak current with the increase in the scanning cycle. The dyes (2-6) show oxidation peaks in the range +200 to $+330 \mathrm{mV}$ due to the formation of azo-hydrazo tautomerism, when the common hydroxyl group present on the naphthalene ring ortho position to the azo group.

Table-3: The Data regarding Cyclic Voltametric Studies

\begin{tabular}{c|c|c|c|c|c|c}
\hline Dyes & $\mathrm{E}_{\mathrm{pc} 1}$ & $\mathrm{E}_{\mathrm{Pc} 2}$ & $\mathrm{I}_{\mathrm{pc} 1}$ & $\mathrm{I}_{\mathrm{PC} 2}$ & $\mathrm{E}_{\mathrm{pa} 1}$ & $\mathrm{I}_{\mathrm{pa} 1}$ \\
\hline Dye-1 & -391.62 & -690.45 & +14.50 & +37.62 & - & - \\
\hline \multicolumn{1}{c}{1639}
\end{tabular}

NOVEL TOLUIC ACID-BASED AZO DYES

A.G. Prashantha et al. 
RASĀYAN J. Chem.

Vol. 14 | No. 3 |1635-1642| July - September | 2021

\begin{tabular}{c|c|c|c|c|c|c}
\hline Dye-2 & -638.5 & - & +23.69 & - & 329.8 & -5.82 \\
\hline Dye-3 & -448.74 & -647.74 & +12.33 & +18.11 & +305.21 & -3.88 \\
\hline Dye-4 & -491.56 & -657.68 & +11.25 & +15.60 & -259.28 & -3.69 \\
\hline Dye-5 & -476.09 & -675.23 & +11.66 & +16.35 & +270.11 & -2.92 \\
\hline Dye-6 & -725.12 & - & 12.80 & - & +200.93 & -3.12 \\
\hline Dye-7 & -467.81 & -605.40 & +9.6 & +11.83 & +268.05 & -2.82 \\
\hline Dye-8 & -685.43 & -999.32 & +13.69 & +25.40 & - & - \\
\hline
\end{tabular}<smiles>[R]N=[NH+]c1cc(C(=O)C[PH3+])ccc1C</smiles><smiles>[R]NNc1cc(C(=O)O)ccc1C</smiles>

\section{Antimicrobial Activity}

Scheme-2: General Reduction Mechanism of Azo Dyes

Aromatic azo compounds are an important class of substances like drugs in chemotherapy. Literature reviews reveal the positive results towards the Antimicrobial activity of azo compounds. Thus the prepared dyes were subjected to primary investigation of antibacterial activity against a common fungus Fusareum oxysporum and bacteria P.aureus and S.aureus of prepared azodyes.

\section{Antifungal Activity}

The antifungal activity of synthesized dyes was studied in comparison with the standard antifungal drug fluconazole by cup plate method.

\section{Antibacterial Activity}

Antibacterial activity against Pseudomonus Auries and Streptococous Auires was carried out by disk diffusion method. Amoxycillin was used as a standard antibacterial drug. The compound concentration was $0.0005 \mathrm{M}\left(5 \times 10^{-4} \mathrm{M}\right)$. The zone of inhibition was compared with the standard drug after $24 \mathrm{hrs}$ at $37^{\circ} \mathrm{C}$. The data relating to the antibacterial activity of standard and compounds are given in Table- 4 and Table-5. Based on the results obtained during the screening of prepared dyes for antimicrobial activity, the following conclusion could be drawn. The dyes 2,4,5 exhibit very good activity against the fungi Fusareum oxysporum, whereas dyes 1,3,8 show moderate activity against the test fungus. The azo dyes 1,2,3,5 and 6 exhibit moderate activity against Bacteria P.aureus and S.aureus.

Table-4

\begin{tabular}{c|c|c|c}
\hline \multirow{2}{*}{} & \multicolumn{3}{|c}{ Zone of inhibition in mili-meters(mm) } \\
\cline { 2 - 4 } & Antifungal Activity & Antibacterial Activity \\
\cline { 2 - 4 } & Fusareum oxysporum & P.aureus & S.aureus \\
\hline Dye-1 & 2 & 3 & 3 \\
\hline Dye-2 & 6 & 2 & 2 \\
\hline Dye-3 & 2 & 3 & 2 \\
\hline
\end{tabular}


RASĀYAN J. Chem.

Vol. 14 | No. 3 |1635-1642| July - September | 2021

\begin{tabular}{c|c|c|c}
\hline Dye-4 & 4 & -- & -- \\
\hline Dye-5 & 5 & 4 & 6 \\
\hline Dye-6 & -- & 2 & 2 \\
\hline Dye-7 & -- & -- & -- \\
\hline Dye-8 & 2 & --- & -- \\
\hline
\end{tabular}

Table-5

\begin{tabular}{|c|c|c|c|}
\hline \multirow{3}{*}{ Treatment } & \multicolumn{3}{|c|}{ Zone of Inhibition in mili-meters(mm) } \\
\hline & \multirow{2}{*}{$\begin{array}{c}\text { Antifungal } \\
\text { Activity }\end{array}$} & \multicolumn{2}{|c|}{$\begin{array}{c}\text { Antibacterial } \\
\text { Activity }\end{array}$} \\
\hline & & P.aureus & S.aureus \\
\hline Amoxycilline & ---- & 8 & 8 \\
\hline Floconazole & 10 & -- & --- \\
\hline DMSO & Nil & Nil & Nil \\
\hline Distilled water & Nil & Nil & Nil \\
\hline
\end{tabular}

CONCLUSION

We have synthesized eight novel toluic acid-based azo dyes and were characterized and confirmed by various analytical methods like IR, ${ }^{1} \mathrm{H}-\mathrm{NMR}$, and Mass spectral techniques. As the dyes are electronically rich and have redox functionalities electrochemical behavior of the newly synthesized compounds were studied by cyclic voltammetry technique and the synthesized dyes were screened for their biological activities like antifungal and antibacterial activities. Synthetic dyes showed a better response than expected.

\section{ACKNOWLEDGEMENT}

The first author is very much thankful to Chairman, Department of Chemistry, Kuvempu University for providing laboratory facilities and for instrumentation facilities particularly for recording UV-Visible and IR spectral data. The authors are very much thankful to IISc, Bangalore for NMR and Mass spectral data.

\section{REFERENCES}

1. M. Satake Y. Mido, Chemistry of Colours, Discovery Publications House, New Delhi (1995).

2. O. D. Tyagi, M. Yadav, Text Book Synthetic Dyes, $1^{\text {st }}$ Ed., Anmol Publication, New Delhi (1993).

3. S. Durmus, A. Atahan, M. Zengin, Spectrochimica Acta, 84(1), 1(2011), https://doi.org/10.1016/j.saa. 2011.07.034

4. H. B. Hassib, S. A. Abdel-latif, Spectrochimica Acta 59(11), 2425(2003), https://doi.org/10.1016/S1386-1425(03)00010-6

5. K. El-Baradie, R. El-Sharkawy, H. El-Ghamry, K. Sakai, Spectrochimica Acta 121,180(2014), https://doi.org/10.1016/j.saa.2013.09.070

6. M. A. Ali, A. H. Mirza, R. J. Butcher, M. T. H. Tarafder, T. B. Keat, A. M. Ali, Journal of Inorganic Biochemistry, 92(3-4), 141(2002), https://doi.org/10.1016/s0162-0134(02)00559-7

7. A. B. Beshir, S. K. Guchhait, J. A. Gascon, G. Fenteany, Bioorganic and Medicinal Chemistry Letters, 18(2), 498(2008), https://doi.org/10.1016/j.bmcl.2007.11.099

8. M. A. Diab, A. Z. El-Sonbati, A. A. El-Bindary, G. G. Mohamed, Sh. M. Morgan, Research on Chemical Intermediate, 41, 9029(2015)

9. R. H. El Halabieh Rolla, O. Mermut, Christopher J. Barret, Pure and Applied Chemistry, 76(78),1445(2004), http://dx.doi.org/10.1351/pac200476071445

10. R.V. Singh, S. C. Joshi, R. Dwivedi, Transition Metal Chemistry, 29, 70(2004), https://doi.org/10.1023/B:TMCH.0000014487.86754.93

11. P. Sudhir Kumar, G. Ghosh, S. K. Rout and D. Paul, Rasayan Journal of Chemistry, 6(2),147(2013).

12. H. Darmokoesoemo, H. Setyawati, A.T.A. Ningtyas and H.S. Kusuma, Rasayan Journal of Chemistry, 10(2), 313(2017), https://doi.org/10.7324/RJC.2017.1021561 
RASĀYAN J. Chem.

Vol. 14 | No. 3 |1635-1642| July - September | 2021

13. N. M. Mallikarjuna, J. Keshavayya, Shoukat Ali R. A, Talavara Venkatesh, Journal of Molecular Structure, 1165, 28(2018), https://doi.org/10.1016/j.molstruc.2018.03.094

14. M. R. Maliyappa, J. Keshavayya, R. A. Shoukat Ali and S. Harisha, Journal of Chemical and Pharmaceutical Sciences, Special Issue, 10(2018)

15. C. T. Keerthi Kumar, J. Keshavayya, T. Rajesh, S. K. Peethambar and R. A. Shoukat Ali, Chemical Science Transactions, 2(4), 1346(2013), https://doi.org/10.7598/cst2013.615

16. R. A. Shoukat Ali, J. Keshavayya and C. T. Keerthi Kumar, Chemical Science Reviews Letters, 5(18), 44(2016)

17. A.G. Prashantha, J. Keshavayya, R.A. Shoukat Ali, Results in Chemistry, 3, 100110(2021), https://doi.org/10.1016/j.rechem.2021.100110

18. A.G. Prashantha, J. Keshavayya , R.A. Shoukat Ali, Inorganic Chemistry Communications, 127 108392(2021), https://doi.org/10.1016/j.inoche.2020.108392

[RJC-6101/2020] 